the Secretary of State for Scotland for financial support; and Dr A B Sclare, consultant psychiatrist, Duke Street Hospital, Glasgow, and $\mathrm{Dr} \mathrm{J} \mathrm{K}$ Binns, consultant psychiatrist, Leverndale Hospital, Glasgow, for encouragement.

\author{
References \\ ${ }^{1}$ Gordon, G G, and Southern, A L, in Metabolic Aspects of Alcoholism, \\ ed C S Lieber, p 249. Lancaster, MTP Press, 1977. \\ 2 Merry, J, and Marks, V, Lancet, 1972, 2, 990. \\ ${ }^{3}$ Chalmers, R J, et al, Psychological Medicine, 1977, 7, 607. \\ ${ }^{4}$ Bergmeyer, H U, and Bernt, E, in Methods of Enzymatic Analysis, ed H U
} Bergmeyer, p 125. Weinheim, Verlag Chemie, 1963.
${ }^{5}$ Morgan, C R, Proceedings of the Society of Experimental and Biological Medicine, 1966, 121, 62.

${ }^{6}$ Reuter, A M, et al, International fournal of Nuclear and Biological Medicine, 1975, 3, 21.

${ }^{7}$ Mattingly, D, Fournal of Clinical Pathology, 1962, 15, 374.

${ }^{-}$Andreani, D, Tamburrano, G, and Javicoli, M, in Hypoglycaemia, Pro- 3 ceedings of the European Symposium in Rome, ed D Andreani, P Lefebvre, $\mathbb{Q}$ and V Marks, p 99. Stuttgart, Thieme, 1976

${ }^{9}$ Noel, G L, Suh, H K, and Frantz, A G, Clinical Research, 1971, 19, 718.

${ }_{10}$ Maany, I, Frazer, A, and Mendels, J, fournal of Clinical Endocrinology and $\overrightarrow{\bar{F}}$ Metabolism, 1975, 40, 162

11 Wright, J, et al, British fournal of Addiction, 1976, 71, 211.

${ }^{12}$ Hore, B J, British fournal of Hospital Medicine, 1977, 18, 106.

(Accepted 18 fanuary 1978)

\title{
Epidemiology and clinical significance of cervical erosion in women attending a family planning clinic
}

\author{
M J GOLDACRE, NANCY LOUDON, B WATT, GRACE GRANT, J D O LOUDON, \\ K MCPHERSON, M P VESSEY
}

British Medical fournal, 1978, 1, 748-750

\section{Summary and conclusions}

Women attending a family planning clinic were studied to determine the relation between cervical erosion and clinical and social characteristics. The appearance of the cervix was recorded without knowledge of the women's symptoms.

The prevalence of erosion increased with parity but, when the effects of other factors were controlled, decreased in women aged 35 and over. Erosion was significantly more common in women taking the "pill" and less common in women using barrier methods of contraception than in others. There was considerable variation between doctors in the reporting of erosion. No association was found between erosion and postcoital bleeding, dyspareunia, backache, or dysuria. There was a significant but modest association between erosion and vaginal discharge and a suggestion that erosion may sometimes be associated with nocturia and frequency of micturition. Vaginal flora was similar in women with and without erosion.

Cervical erosion should not be regarded as pathological in asymptomatic women, nor should it be assumed necessarily to be the cause of symptoms in women with genitourinary complaints.

\footnotetext{
Department of Social and Community Medicine, University of Oxford, Oxford OX1 3QN

M J GOLDACRE, BM, MFCM, lecturer

$\mathrm{K}$ MCPHERSON, PHD, lecturer in medical statistics

M P VESSEY, MD, FFCM, professor

Edinburgh Family Planning Centre, Edinburgh EH4 1NL

NANCY LOUDON, MB, medical co-ordinator, family planning services GRACE GRANT, SRN, research nurse

Western General Hospital, Edinburgh EH4 2XU

B WATT, MD, consultant microbiologist

Eastern General Hospital, Edinburgh EH6 7LN

J D O LOUDON, FRCS, FRCOG, consultant obstetrician and gynaecologist
}

\author{
Introduction
}

Cervical erosion is one of the most common reasons for hospital $\vec{\varphi}$ admission of women aged 15-44 years. It accounts for about 9 5000 admissions a year in Scotland and 30000 admissions a year in England and Wales. ${ }^{2}$ In addition an unknown number of women with erosions are treated as outpatients. The term $\bar{\partial}$ erosion is misleading, since there is no loss of surface tissue from the cervix ${ }^{3}{ }^{4}$ : the lesion consists of a zone of columnar $\stackrel{\mathbb{D}}{\square}$ epithelium on the vaginal portion of the cervix in place of the stratified, squamous epithelium normally found below the external os.

Cervical erosion is a common finding on routine pelvic examination during the fertile years, ${ }^{56}$ but whether it should be treated or ignored remains controversial. Many doctors refer for specialist treatment only those women in whom the erosion is associated with genitourinary symptoms. Even in these patients, however, it is not certain that the lesion causes the symptoms, since similar symptoms also occur in women with a normal cervix. Uncertainty about the clinical significance of cervical erosion results in substantial variation in its management. For example, Philip ${ }^{7}$ recommended that most erosions in $N$ non-puerperal women should be treated, whereas Townsend ${ }^{*}$ thought that treatment should be reserved for selected, symptomatic cases. This leads to uncertainty about the need to refer women with erosion for specialist care-in one study ${ }^{9}$ the rate of referral for treatment of erosion varied seventeenfold among different family planning clinics.

Because cervical erosion is so common and its clinical significance often obscure we undertook a study to describe the characteristics of women with erosion and determine the relation between genitourinary symptoms and erosion. Clinical signs were recorded "blind"-that is, without knowledge of the women's symptoms.

\section{Patients and methods}

The study was conducted from October 1975 to March 1977 in the family planning centre at Edinburgh. Patients included were either new attenders or attenders who had not been seen for at least six months. In an attempt to standardise the recognition and description of erosions the seven participating clinic doctors received instruction from a consultant gynaecologist (JDOL).

Each patient was asked to participate in a survey of "common symp- 
toms in young women." She was interviewed by a research nurse, who recorded personal and social characteristics and present and past symptoms by means of a standard questionnaire (see Appendix). Each woman was then told that she would be examined by a doctor but should not discuss any symptoms until after the examination. The research nurse accompanied each patient to explain the procedures and verify that no discussion took place until the doctor had completed the examination form. Thus physical findings were recorded without knowledge of reported symptoms. Cervical erosions were graded as less or more than $2 \mathrm{~cm}$ in diameter.

Albumin-coated swabs (Exogen Ltd) were taken from the external os of all women, the site of any erosion, and the vaginal fornix in women with an abnormal vaginal discharge. All swabs were taken under direct vision through a vaginal speculum, care being taken to minimise the possibility of contaminating a swab from one site with material from another. Swabs were examined for Trichomonas vaginalis, Neisseria gonorrhoeae, and yeasts and fungi and were also cultured on routine laboratory media for aerobic and anaerobic bacteria. Other groups of organisms were defined as follows: (1) anacrobes-obligate anaerobic cocci and Gram-negative bacilli that were sensitive to metronidazole and failed to grow in $10 \% \mathrm{CO}_{2}$ in air; (2) coliform organisms-Gram-negative bacilli growing aerobically on MacConkey medium at $37 \mathrm{C}$; and (3) $\beta$-haemolytic streptococci-streptococci showing 3 -haemolysis on $10 \%$ horse-blood agar. Full details of sampling, transport, and isolation procedures will be reported elsewhere, together with detailed results of the microbiological studies.

\section{Results}

We studied 1498 women aged 16-47 years (mean age 27). A large erosion ( $2 \mathrm{~cm}$ in diameter) was reported in 151 women $(10.1 \%)$ and a smaller one in $399(26.6 \%)$. Large erosions were more common in women aged 25 and over (table I) and were associated with increasing parity (table II). They were more common in women taking the "pill" and less common in women using barrier methods of contraception than in women using either no method or an intrauterine

TABLE I-Prevalence of erosion in each age group

\begin{tabular}{l|c|c|c|c}
\hline \multirow{2}{*}{$\begin{array}{c}\text { Age group } \\
\text { (years) }\end{array}$} & \multicolumn{2}{|c|}{ No ("..) of women with cervical epithelium: } & \multirow{2}{*}{ Total } \\
\cline { 2 - 3 } & Intact & Eroded <2 cm & Eroded 2 cm & \\
\hline $16-24$ & $446(63)$ & $211(30)$ & $54(7)$ & $711(100)$ \\
$25-34$ & $274(59)$ & $133(29)$ & $57(12)$ & $464(100)$ \\
$35-47$ & $228(71)$ & $55(17)$ & $40(12)$ & $323(100)$ \\
\hline Total & $948(63)$ & $399(27)$ & $151(10)$ & $1498(100)$ \\
\hline
\end{tabular}

$\chi^{2}\left({ }_{4}\right)=26 \cdot 74 ; P<0.001$.

TABLE II-Prevalence of erosion according to parity

\begin{tabular}{|c|c|c|c|c|c|}
\hline \multirow{2}{*}{\multicolumn{2}{|c|}{ Parity }} & \multicolumn{3}{|c|}{ No $\left({ }^{\prime}{ }_{0}\right)$ of women with epithelium: } & \multirow{2}{*}{ Total } \\
\hline & & Intact & Eroded $<2 \mathrm{~cm}$ & Eroded $2 \mathrm{~cm}$ & \\
\hline $\begin{array}{l}0 \\
1 \text { or } 2 \\
3 \text { or more }\end{array}$ & $\begin{array}{l}\ldots \\
\cdots\end{array}$ & $\begin{array}{r}575(63) \\
278(64) \\
95(63)\end{array}$ & $\begin{array}{r}269(29) \\
99(23) \\
31(20)\end{array}$ & $\begin{array}{l}70(8) \\
56(13) \\
25(17)\end{array}$ & $\begin{array}{l}914(100) \\
433(100) \\
151(100)\end{array}$ \\
\hline Total & & $948(63)$ & $399(27)$ & $151(10)$ & $1498(100)$ \\
\hline
\end{tabular}

$\%^{2}\left({ }_{4}\right)=22 \cdot 28 ; \mathrm{P}<0.001$.

TABLE III-Prevalence of erosion according to method of contraception

\begin{tabular}{|c|c|c|c|c|c|}
\hline \multirow{2}{*}{\multicolumn{2}{|c|}{$\begin{array}{l}\text { Method of } \\
\text { contraception }\end{array}$}} & \multicolumn{3}{|c|}{ No $\left({ }^{\circ},\right)$ of women with epithelium: } & \multirow[b]{2}{*}{ Total } \\
\hline & & Intact & $\begin{array}{l}\text { Eroded } \\
<2 \mathrm{~cm}\end{array}$ & $\begin{array}{c}\text { Eroded } \\
2 \mathrm{~cm}\end{array}$ & \\
\hline $\begin{array}{l}\text { None } \quad \ldots \\
\text { Pill } \\
\text { Intrauterine device } \\
\text { Diaphragm/sheath }\end{array}$ & $\begin{array}{l}\ldots \\
\cdots \\
\cdots\end{array}$ & $\begin{array}{l}256(68) \\
268(49) \\
108(74) \\
316(74)\end{array}$ & $\begin{array}{r}86(23) \\
195(36) \\
24(16) \\
94(22)\end{array}$ & $\begin{array}{l}36(9) \\
83(15) \\
14(10) \\
18(4)\end{array}$ & $\begin{array}{l}378(100) \\
546(100) \\
146(100) \\
428(100)\end{array}$ \\
\hline Total & & $948(63)$ & $399(27)$ & $151(10)$ & $1498(100)$ \\
\hline
\end{tabular}

$\chi^{2}\left({ }_{6}\right)=86.04 ; \mathrm{P}<0 \cdot 001$
TABLE IV-Prevalence of symptoms, and associations between symptoms and erosion

\begin{tabular}{|c|c|c|c|c|c|c|}
\hline \multirow{2}{*}{ Symptom } & & \multicolumn{3}{|c|}{$\begin{array}{c}\text { No }(\%) \text { of women with } \\
\text { epithelium: }\end{array}$} & \multirow{2}{*}{$\begin{array}{c}\text { No }(\%) \\
\text { with each } \\
\text { symptom } \\
(\mathrm{n}=1498)\end{array}$} & \multirow{2}{*}{$x^{2}\left({ }_{2}\right)$} \\
\hline & & $\begin{array}{c}\text { Intact } \\
(\mathbf{n}=948)\end{array}$ & $\begin{array}{c}\text { Eroded } \\
<2 \mathrm{~cm} \\
(\mathrm{n}=399)\end{array}$ & $\begin{array}{c}\text { Eroded } \\
2 \mathrm{~cm} \\
(\mathrm{n}=151)\end{array}$ & & \\
\hline $\begin{array}{l}\text { Vaginal discharge } \\
\text { Vulval itch } \\
\text { Low backache } \\
\text { Postcoital bleeding } \\
\text { Dyspareunia } \\
\text { Frequency of }\end{array}$ & $\begin{array}{l}\cdots \\
\cdots \\
\cdots \\
\cdots\end{array}$ & $\begin{aligned} 152(16) \\
83(9) \\
148(16) \\
45(5) \\
36(4)\end{aligned}$ & $\begin{array}{l}70(18) \\
40(10) \\
57(14) \\
23(6) \\
14(4)\end{array}$ & $\begin{array}{c}37(25) \\
13(9) \\
29(19) \\
8(5) \\
8(5)\end{array}$ & $\begin{array}{c}259(17) \\
136(9) \\
234(16) \\
76(5) \\
58(4)\end{array}$ & $\begin{array}{l}6 \cdot 6^{*} \\
0 \cdot 6 \\
2 \cdot 0 \\
0 \cdot 6 \\
1 \cdot 0\end{array}$ \\
\hline $\begin{array}{ll}\underset{\text { micturition }}{\text { mocturia }} & \ldots \\
\text { Dysuria } & . .\end{array}$ & $\begin{array}{l}\cdots \\
\cdots\end{array}$ & $\begin{array}{l}114(12) \\
108(11) \\
22(2)\end{array}$ & $\begin{array}{l}55(14) \\
47(12) \\
8(2)\end{array}$ & $\begin{array}{l}29(19) \\
32(21) \\
2(1)\end{array}$ & $\begin{aligned} 198(13) \\
187(12) \\
32(2)\end{aligned}$ & $\begin{array}{l}6 \cdot 0^{*} \\
11 \cdot 7^{* *} \\
0 \cdot 7\end{array}$ \\
\hline
\end{tabular}

${ }^{*} \mathrm{P}<0.05 .{ }^{* *} \mathrm{P}<0 \cdot 01$

TABLE $\mathrm{v}-$ Consistency of vaginal discharge on examination

\begin{tabular}{|c|c|c|c|c|c|}
\hline \multirow{2}{*}{\multicolumn{2}{|c|}{$\begin{array}{l}\text { Consistency of } \\
\text { vaginal } \\
\text { discharge }\end{array}$}} & \multicolumn{3}{|c|}{ No $(", 1)$ of women with epithelium: } & \multirow{2}{*}{$\begin{array}{l}\text { No }(\%) \\
\text { in each } \\
\text { group }\end{array}$} \\
\hline & & Intact & $\begin{array}{l}\text { Eroded } \\
<2 \mathrm{~cm}\end{array}$ & $\begin{array}{l}\text { Eroded } \\
2 \mathrm{~cm}\end{array}$ & \\
\hline $\begin{array}{ll}\text { Normal... } & \ldots \\
\text { Mucopurulent } & \ldots \\
\text { Purulent } & \ldots \\
\text { Bloodstained } & \ldots \\
\text { Other* .. } & \ldots\end{array}$ & $\begin{array}{l}\cdots \\
\cdots \\
\cdots \\
\cdots\end{array}$ & $\begin{array}{c}642(68) \\
184(19) \\
14(1) \\
4(<1) \\
104(11)\end{array}$ & $\begin{array}{l}224(56) \\
135(34) \\
6(2) \\
1(<1) \\
33(8)\end{array}$ & $\begin{array}{r}66(44) \\
68(45) \\
2(1) \\
3(2) \\
12(8)\end{array}$ & $\begin{array}{c}932(62) \\
387(26) \\
22(1) \\
8(1) \\
149(10)\end{array}$ \\
\hline Other* $\ldots \quad \ldots$ & & $948(100)$ & $399(100)$ & $151(100)$ & $1498(100)$ \\
\hline
\end{tabular}

*Described as watery, curdy, creamy, or frothy.

device (table III). There was considerable variation between doctors in the reporting of erosion. In particular, the reporting of large erosions ranged from $3 \%$ of women seen by one doctor to $19 \%$ of those seen by another. No association was found between erosion and either social class or the use of tampons.

Age, parity, and contraceptive method were substantially intercorrelated. To take account of this and the difference between the examining doctors we analysed the data by means of a multiple logit model. ${ }^{1011}$ This enables the effect of one factor on an observation to be estimated after allowing for the effects of others; an appropriate $\chi^{2}$ test can then be carried out on the results. In this way we determined the relation between cervical erosion and each of four variables (age, parity, contraceptive method, and examining doctor) while controlling for the effects of the other three. We found that parity had an independent effect: increased parity was associated with an increased prevalence of both large erosions $\left(\chi^{2}\left({ }_{2}\right)=14.6 ; P<0.01\right)$ and all erosions $\left(\chi^{2}\left({ }_{2}\right)=8.4 ; \quad P<0.05\right)$. The association with all erosions was not apparent from the unadjusted data (table II). When the effects of parity and contraceptive method were taken into account the increased prevalence of large erosions in women aged 25 years and over (table I) was no longer apparent. Indeed, the prevalence of erosions of any size was significantly lower in women aged 35 and over $\left(\gamma^{2}\left({ }_{2}\right)=12.4 ; \mathrm{P}<0.01\right)$ than in younger women. Thus age and parity exerted effects in opposite directions, with the prevalence of erosion tending to increase with parity in the fertile years but decrease with age. The increased prevalence of erosion associated with use of the pill and the decreased prevalence associated with barrier methods of contraception remained highly significant in the logit analysis $(\mathrm{P}<0.001)$

We found no association between erosion and vulval itching, low backache, postcoital bleeding, or dyspareunia (table IV) but did find an association between erosion and troublesome vaginal discharge, frequency of micturition, and nocturia. Logit analysis (controlling as before for the effects of age, parity, contraceptive method, and different doctors) slightly strengthened the association between erosion and vaginal discharge $\left(\chi^{2}\left({ }_{2}\right)=8.3 ; P<0.05\right)$ but weakened the associations between erosion and frequency of micturition $\left(\chi^{2}\left(_{2}\right)=\right.$ $4.3 ; \mathrm{NS})$ and nocturia $\left(\chi^{2}\left({ }_{2}\right)=6.8 ; \mathrm{P}<0.05\right)$. We compared the women's descriptions of vaginal discharge between women with and without an erosion. Those with an erosion were more inclined to describe their discharge as moderate (as distinct from heavy or light), thick, and yellow or creamy. Erosion was unrelated to bloodstaining, odour, or variation with the menstrual cycle, of vaginal discharge.

The doctors graded the quantity of vaginal discharge seen on 
examination as normal, slightly more than normal, or much more than normal. A much greater than normal discharge was reported for $6 \%$ of the women with a normal cervix, $10 \%$ of those with a small erosion, and $17 \%$ of those with a large erosion. The doctors tended to grade the consistency of vaginal discharge as mucopurulent more often in women with erosions than in those without (table V). There was no appreciable difference in the prevalence of yeasts and fungi, $T$ vaginalis, and $N$ gonorrhoeae between women with and without erosions. The flora from the os was similar in the two groups of women; and, in women with an erosion, the flora from the os and erosion was also similar (table VI).

TABLE VI-Prevalence of micro-organisms in swabs from cervical os of all 1498 women and from erosions of 550 women

\begin{tabular}{|c|c|c|c|c|c|}
\hline \multirow[b]{2}{*}{ Organism } & \multicolumn{3}{|c|}{$\begin{array}{l}\text { No ( }{ }^{(1)} \text { ()) of women with micro- } \\
\text { organisms in cervical os }\end{array}$} & \multicolumn{2}{|c|}{$\begin{array}{l}\text { No }\left({ }^{\circ} 0\right) \text { with micro- } \\
\text { organisms in erosion }\end{array}$} \\
\hline & $\begin{array}{l}\text { Epithelium } \\
\text { intact } \\
(\mathrm{n}=948)\end{array}$ & $\begin{array}{l}\text { Epithelium } \\
\text { eroded } \\
<2 \mathrm{~cm} \\
(\mathrm{n}=399)\end{array}$ & $\begin{array}{l}\text { Epithelium } \\
\text { eroded } \\
22 \mathrm{~cm} \\
(\mathrm{n}=151)\end{array}$ & $\begin{array}{c}\text { Erosion } \\
<2 \mathrm{~cm} \\
(\mathrm{n}=399)\end{array}$ & $\begin{array}{c}\text { Erosion } \\
2 \mathrm{~cm} \\
(\mathrm{n}=151)\end{array}$ \\
\hline Yeasts and fungi & $185(19 \cdot 5)$ & $69(17 \cdot 3)$ & $26(17 \cdot 2)$ & $73(18 \cdot 3)$ & $26(17 \cdot 2)$ \\
\hline vaginalis & $4(0 \cdot 4)$ & $1(0 \cdot 3)$ & $3(2 \cdot 0)$ & $1(0 \cdot 3)$ & $4(2 \cdot 6)$ \\
\hline $\begin{array}{l}\text { Neisseria } \\
\text { gonorrhoeae }\end{array}$ & $1(0 \cdot 1)$ & $1(0 \cdot 3)$ & & $(0.3)$ & \\
\hline $\begin{array}{l}\text { Anaerobes* } \\
\text { Coliform }\end{array}$ & $157(16 \cdot 6)$ & $56(14 \cdot 0)$ & $24(15 \cdot 9)$ & $63(15 \cdot 8)$ & $25(16 \cdot 6)$ \\
\hline $\begin{array}{c}\text { organisms* } \\
\text { B-Haemolytic }\end{array}$ & $145(15 \cdot 3)$ & $47(11 \cdot 8)$ & $21(13.9)$ & $53(13.3)$ & $24(15 \cdot 9)$ \\
\hline streptococci* & $32(3 \cdot 4)$ & $22(5 \cdot 5)$ & $5(3 \cdot 3)$ & $25(6 \cdot 3)$ & $8(5 \cdot 3)$ \\
\hline
\end{tabular}

*Significant growth of organisms.

\section{Discussion}

These findings confirm that some degree of cervical erosion is common in women of fertile age. ${ }^{5}{ }^{6}$ Large erosions were found in $10 \%$ of our study population. The prevalence of erosion increased with parity but, when the effects of other factors were controlled, decreased with age over 35 ; indeed, it is recognised that erosion is uncommon in postmenopausal women. ${ }^{+}$Erosions were significantly more common in women taking the pill, which supports the possibility that erosion is at least partly aetiologically related to hormonal status. Erosion was significantly less common in women using barrier methods of contraception-namely, the diaphragm or sheath. There was considerable variation between doctors in the reporting of erosion, despite efforts to standardise their observations.

Symptoms commonly ascribed to cervical erosion include vaginal discharge, postcoital bleeding, dyspareunia, backache, and disturbances of micturition. Although some erosions were recorded as having bled easily when touched during the examination, we found no association between erosion and symptomatic postcoital bleeding. Furthermore, women with erosion were no more likely than those without to report bloodstained or brown vaginal discharge. We found no correlation between erosion and dyspareunia, backache, or dysuria. There was, however, a significant association between erosion and vaginal discharge. The presence of erosion and abnormal vaginal discharge on examination could not, of course, be ascertained independently, which was a potential source of bias; but the finding of erosion was independent of knowledge of the symptom of vaginal discharge (table IV), so that this association was free from such bias. Patients with erosion who had abnormal discharge tended to describe it as moderate in quantity, thick, and yellow or creamy. This corresponded reasonably well with the doctors' tendency to describe such discharge as being heavier than normal and mucopurulent. The microbiological flora in women with erosions was no different from that in other women (table VI), however, and the vaginal discharge associated with erosion was therefore probably related to the secretory function of the columnar epithelium rather than being the result of an infective process. (The prevalence of viruses, T-strain mycoplasmas, and Chlamydia spp was not investigated in this study.) The association between erosion and discharge (table IV) was modest: hence even when an erosion is found in a woman with abnormal discharge it should not necessarily be regarded as the cause of the discharge. There was a suggestion in the data that erosion may be associated in some women with frequency of micturition and nocturia (most commonly the need to pass urine once in the night).

The population of women studied was unselected except that $\stackrel{\mathbb{Q}}{\varrho}$ they had sought advice on contraception from a family planning clinic. The results are therefore relevant to the finding of cervical erosion on routine pelvic examination in family planning clinics and general practice. We cannot tell how relevant they are to women seen with erosion in specialist gynaecological clinics. We suggest, however, that cervical erosion should not be regarded as either pathological in asymptomatic women or necessarily the cause of symptoms in women with genitourinary complaints. Controlled trials are needed to determine the value of surgery, measuring the alleviation of symptoms thought to be associated with erosion.

This study was financed by a grant from the Scottish Home and Health Department. We thank the doctors at the Edinburgh Family of Planning Centre who participated in the study-namely, Dr Agnes Begg, Dr Isabel Herbert, Dr Kathleen G Macleod, Dr Marion More, Dr Anne L Munro, Dr Rhoda Scott, and Dr Elizabeth Sudlow. We also thank the nursing staff, particularly Mrs Mary Rankin and Mrs Margaret Foxwell; and Mr D J Annat and Dr L J R Milne for help with the microbiological examinations.

\section{Appendix}

STEM QUESTIONS USED TO ELICIT SYMPTOMS

(1) Do you suffer from troublesome vaginal discharge at present?

(2) Do you suffer from itching of the vulva?

(3) Do you suffer from low backache?

(4) Do you experience blood spotting after intercourse?

(5) Do you find intercourse painful?

(6) Do you have to pass water more frequently than other people you know?

(7) How often do you have to get up at night to pass water?

(8) Do you have pain or burning on passing water?

If women answered in the affirmative, structured subsidiary questions were asked about each symptom.

\section{References}

${ }^{1}$ Scottish Health Service Common Services Agency, Information Services Division, personal communication.

2 Department of Health and Social Security, Report on the Hospital InPatient Enquiry. London, HMSO, annual.

${ }^{3}$ Fluhmann, C F, American fournal of Obstetrics and Gynecology, 1961, 82, 970.

${ }^{4}$ Hamperl, H, and Kaufmann, C, Obstetrics and Gynecology, 1959, 14, 621.

5 Davey, J B, Greening, W P, and McKinna, J A, British Medical fournal, 1970, 3, 696.

${ }^{6}$ Edwards, D, British Medical fournal, 1974, 4, 218

7 Philip, E E, Obstetrics and Gynaecology, p 452. London, Lewis, 1970 .

8 Townsend, D E, in The Cervix, ed J A Jordan and A Singer. Philadelphia, Saunders, 1976.

${ }^{9}$ Vessey, M P, et al, fournal of Biosocial Science, 1976, 8, 373.

${ }_{10}$ Walker, S H, and Duncan, B, Biometrika, 1967, 54, 167.

11 Nelder, J A, General Linear Interactive Modelling. Oxford, Numerical Algorithms Group, 1975.

(Accepted 3 fanuary 1978)

\section{,

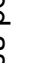 .

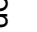

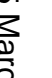

.

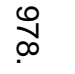

